Sains Malaysiana 50(5)(2021): 1277-1284

http://doi.org/10.17576/jsm-2021-5005-08

\title{
The Effect of MS Media Strength and Cytokinin in the Induction of Shoots from Shoot Tip Explants of Australian Finger Lime (Citrus australasica cv. Tasty Green) \\ (Kesan Kekuatan Medium MS dan Sitokinin dalam Aruhan Pucuk daripada Hujung Pucuk Eksplan Limau Jejari Australia (Citrus australasica cv. Tasty Green))
}

\author{
DAHMEndra SRiskanda, Khoy Siong Poi, NAJWA Amalina Haradzi, Nurulhikma Md Isa, SREERAmANAN \\ SubRAMANiAM \& BEE LYNN CHEW*
}

\begin{abstract}
The Australian Finger Lime (Citrus australasica) is a type of citrus from the Rutaceae family, endemic to the east coast of Australia. The finger lime, loaded with numerous vitamins and renders a unique taste, has also been backed by science to contain essential amounts of antioxidants that are beneficial for cell protection, immune response, cancer prevention, ageing, arthritis and prevention of kidney stones. Current propagation attempts still rely on conventional methods that are less efficient and resulted in the slow establishment of farms for finger lime especially for commercialization purposes. This study focuses on the induction of shoots from shoot tip explants using 6-Benzylaminopurine (BAP) and Kinetin. Aseptic explants were inoculated into Murashige and Skoog (MS) medium of full-strength and half-strength followed by full-strength MS media supplemented with different concentrations of BAP and Kinetin. Results obtained in this study showed no significant differences in terms of the number of axillary shoots produced between explants cultured in full and half-strength MS media. However, the highest number of shoots and increment in shoot length were obtained from MS media supplemented with $2.0 \mathrm{mg} / \mathrm{L}$ BAP with the values $1.80 \pm 0.27$ and $2.56 \pm 0.36 \mathrm{~cm}$, respectively. In conclusion, MS media supplemented with $2.0 \mathrm{mg} / \mathrm{L}$ BAP was found optimal in the induction of shoots and shoot elongation of C. australasica cv. Tasty Green.
\end{abstract}

Keywords: 6-Benzylaminopurine; Australian Finger Lime; axillary shoots; Citrus australasica; kinetin

ABSTRAK

Citrus australasica yang dikenali sebagai Limau Jejari Australia adalah daripada famili Rutaceae yang biasanya terdapat di pantai timur Australia. Limau ini kaya dengan pelbagai jenis vitamin dan mempunyai rasa yang unik, serta telah terbukti secara saintifik mempunyai kandungan antioksida yang penting untuk perlindungan sel, tindak balas imun, perlindungan terhadap kanser, penuaan, artritis dan pencegahan batu karang. Propagasi pokok limau ini masih bergantung pada kaedah konvensional yang kurang cekap dan menyukarkan penubuhan ladang limau ini terutamanya untuk tujuan komersial. Kajian semasa memfokuskan kepada penginduksian pucuk daripada eksplan pucuk menggunakan Benzilaminopurina (BAP) dan Kinetin. Eksplan steril dikultur dalam media Murashige dan Skoog (MS) pada kekuatan penuh dan separuh, serta MS berkekuatan penuh dengan penambahan BAP dan Kinetin. Keputusan daripada kajian ini menunjukkan tiada perbezaan yang signifikan dari segi jumlah pucuk aksilari yang dihasilkan antara eksplan yang dikultur dalam media MS kekuatan penuh dan separuh. Walau bagaimanapun, bilangan pucuk dan pertambahan ketinggian eksplan diperoleh dalam media MS pada kekuatan penuh ditambah dengan $2.0 \mathrm{mg} / \mathrm{L}$ $B A P$ dengan nilai masing-masing $1.80 \pm 0.27$ dan $2.56 \pm 0.36 \mathrm{~cm}$. Kesimpulannya, media MS yang ditambah dengan $2.0 \mathrm{mg} / \mathrm{L}$ BAP didapati lebih optimum daripada rawatan yang lain dalam penginduksian pucuk dan pemanjangan pucuk C. australasica cv. Tasty Green.

Kata kunci: 6-benzilaminopurina; Citrus australasica; kinetin; Limau Jejari Australia; pucuk aksilari 


\section{INTRODUCTION}

The Finger Lime (Citrus australasica), a fruit resembling finger-like shape, is placed amongst four other native citrus species, endemic to the rainforests in the east coast of Australia (Mabberley 1998). The other common name, caviar lime, is also attributed to this species as the globular vesicles of the pulp resemble caviar. Finger limes are grouped into the same family as other citruses, namely Rutaceae (Delort \& Jaquier 2009).

Finger lime fruit is equipped with a unique shape, aroma, and colour (Delort \& Jaquier 2009). This distinctive citrus species life form is generally shrub-like and can develop into a small tree up to 6 meters in height. Morphologically, the leaves are smaller compared to other citruses, and they have thorny stems. The small leaves and fruit peel are enriched with aromatic oil glands (Koskinen 2016). The fruit is cylindrical, and the flowers are typically white with small seeds produced that are whitish cream. This species harbours various cultivars that contribute to the diversity in pulp colours ranging from green, brown, pink and red (Koskinen 2016). Some of the established cultivars include the Alstonville, Blunobia Pink Crystal, Durham's Emerald, Judy's Everbearing, Pink Ice, Byron Sunrise and Jali Red, and these cultivars are currently registered under the Australian Cultivar Registration Authority (ACRA) (Delort et al. 2015).

Finger lime which contains juicy vesicles resembling caviar can be either directly consumed or used as a garnish as it provides a unique flavour element. Fresh fruits can be juiced or used as a flavouring agent in various food products (Delort et al. 2015). The finger lime fruits are expensive but the demand for these fruits has resulted in a boost of its export price for the domestic fresh fruit market (Hardy et al. 2010). The high nutritional content in this fruit gives an important role in various ailments. Kawaii et al. (2001) reported the presence of the Byangelicin compound in finger lime, is linked to the prevention of cell damage, encouraging cell regeneration and reducing the risk of cancer. The presence of phenolic compounds and significant antioxidants in the finger lime fruit was found to aid cell protection, as well as in reducing oxidative stress associated with diseases such as cancer, cardiovascular diseases, and neurodegenerative diseases (Netzel et al. 2007; Pham-Huy et al. 2008). Vitamin C is present abundantly in all cultivars and, the pink variety was found to be three times higher than that of in mandarin oranges (Konczak et al. 2010). Vitamin C is known to be highly capable of scavenging free radicals and provides photoprotection from UVA and UVB (Stamford 2012). Vitamin
E on the other hand is also present in finger limes and has been found to be linked to cancer prevention, ageing, arthritis, and cataract (Rizvi et al. 2014).

Finger lime plants are propagated through conventional methods similar to other citruses, such as grafting, seed germination or cuttings. Nevertheless, these methods in finger lime cultivation were more futile or less effective in producing healthy or viable cuttings. Other conventional methods such as budding and grafting rendered a high susceptibility to virus infection from the original mother plant (Shende \& Manik 2015). Hardy et al. (2010) also highlighted the vulnerability of the finger lime species to various diseases and pests such as aphids, bronze orange bugs, caterpillars, snails, katydids, and grasshoppers resulting in reduced quality and quantity of fruit production. Besides, fungal infection such as melanose, gummosis, phytophtera, and dry fusarium rot significantly impacts plant health, thereby reducing fruit yield (Hardy et al. 2010). Issues involving this species that is prone to such pests and diseases severely impedes attempt for commercialization at a massive fruit production scale to cater global demand (Yasmina \& Fazal 2016).

Plant tissue culture is an efficient alternative in mass propagating numerous elite plants yielding genetically identical clones of the mother plants. This technique varies in terms of culture conditions, plant growth regulators and plant media to optimise the production of desired propagules. C. australasica is commonly grown in the northeast of Australia and is not widely grown due to the low availability of plant stocks. Conventional methods applied in propagation finger lime plants such as grafting and cuttings are of low efficiency, tedious, and can be time consuming. Previous studies on tissue culture of citrus reported the suitability of MS media with the supplementation of different cytokinins such as BAP and Kinetin singly or in combination to induce multiple shoots particularly for micropropagation purposes (Fatonah et al. 2018; Silva et al. 2010). Therefore, the current study aims to evaluate the effects of MS media strength and the supplementation of cytokinin such as BAP and Kinetin in the induction of shoots from axillary shoot tip explants $C$. australasica cv. Tasty Green for future micropropagation attempts especially for the commercialization of this citrus.

\section{Materials AND Methods}

SOURCE OF EXPLANTS

The mother plants of $C$. australasica cv. Tasty Green 
were obtained from the Superfruit Valley, Chuping, Perlis, Malaysia. The two-year-old plants were maintained at the School of Biological Sciences, Universiti Sains Malaysia under standard growing practices and fertilized weekly with NPK fertilizers at a ratio of 13:7:13. Young shoot tips of $C$. australasica cv. Tasty Green at the length of $3 \mathrm{~cm}$ long were excised and the thorns were removed prior to surface sterilization.

\section{EXPLANT SURFACE STERILIZATION}

Shoot tip explant were immersed in tap water containing $4 \%$ (v/v) Sunlight ${ }^{\circledR}$ dishwashing detergent liquid added with a few drops of tween-20 for 10-15 min with gentle brushing. The explants were then rinsed under running tap water for $30 \mathrm{~min}$ to remove detergent residues and soil particles. The cleaned shoot tip explants were sterilized by agitation in $70 \%(\mathrm{v} / \mathrm{v})$ ethanol for $1 \mathrm{~min}$, followed by $80 \%$ of commercial bleaching solution (Clorox ${ }^{\circledR}$ RegularBleach) for $7 \mathrm{~min}$ and rinsed 5 times with sterile distilled water. The sterile explants were blot dry on filter paper for $5 \mathrm{~min}$ and then excised into approximately $2 \mathrm{~cm}$ length before inoculated on full-strength MS (Murashige and Skoog) media. All explants were maintained in culture at 16 $\mathrm{h}$ light and $8 \mathrm{~h}$ dark photoperiod and $25 \pm 2{ }^{\circ} \mathrm{C}$ under white fluorescent light (Philips TLD, $36 \mathrm{~W} .150 \mu \mathrm{mol} \mathrm{m} \mathrm{m}^{-2} \mathrm{~s}^{-1}$ ).

\section{THE INDUCTION OF SHOOTS IN DIFFERENT STRENGTHS OF MS MEDIA}

Sterile shoot tip explants were cultured on both full and half-strength MS media without plant growth regulators. The number of shoots induced from both media were recorded and analysed after 6 weeks of culture.

\section{SHOOT INDUCTION USING BAP AND KINETIN}

The sterile shoot tip explants were inoculated on full-strength MS media supplemented with different concentrations of BAP $(0.1,0.5,1.0,2.0,3.0$, and $4.0 \mathrm{mg} / \mathrm{L})$ and Kinetin $(0.1,0.5,1.0,2.0,3.0$, and $4.0 \mathrm{mg} / \mathrm{L})$. The explants were sub-cultured after 4 weeks. The percentage of shoot induction, the number of shoots induced per explant and the average length of induced shoots were evaluated after 6 weeks of culture.

\section{STATISTICAL ANALYSIS}

All data were analysed using IBM SPSS Statistical 24 software. Data obtained from the induction of shoots in different strengths of MS media was subjected to
Independent T-test, whereas the data obtained from the induction of shoots using BAP and Kinetin were subjected to One-Way Analysis of Variance (ANOVA) followed by Duncan's Multiple Range Test at the significance level of $\mathrm{p} \leq 0.05$.

\section{RESULTS AND DISCUSSION}

THE INDUCTION OF SHOOTS IN DIFFERENT STRENGTHS OF MS MEDIA

Sterile shoot tips of $C$. australasica were cultured on full-strength and half-strength MS media. The percentage of shoots induced from shoot tip explants on full and half-strength media were 65 and $60 \%$, respectively, after 6 weeks of culture. With reference to Table 1 , there is no significant difference between these values, indicating that both MS media strength can be used throughout the study.

Previous works of literature on citrus has reported the preference of using full-strength MS media for shoot induction and half-strength MS media for root induction. A recent study conducted on $C$. australasica used fullstrength MS media for the induction of shoots, whereas half-strength MS media was used to induce roots (Mahmoud et al. 2020). The utilisation of full-strength MS media in rendering the maximum number of shoots induced were also observed in various Citrus species, such as Citrus aurantifolia with the average of 8 shoots per node (Al-Khayri \& Al-Bahrany 2001) and Citrus megaloxycarpa with the mean number shoots of 4.7 (Haripyaree et al. 2011). Other citrus plants were also found to produce a maximum number of in vitro shoots in full-strength MS media such as Citrus reticulata at 3.4 shoots (Shende \& Manik 2015), Citrus halimii at 3.7 shoots (Normah et al. 1997) and Citrus limon L. cv. Kaghzi Kalan at 5.5 shoots per explant (Goswami et al. 2013). The reason behind full strength media rendering only 1.35 shoots can be attributed to the fact that other citrus species as reported by Vibhute et al. (2012) genotypically responded to the full-strength media, thereby resulting in differences to the number of induced shoots

With reference to the work of Rathore et al. (2007), MS media with half the concentration of ammonium nitrate $\left(\mathrm{NH}_{4} \mathrm{NO}_{3}\right)$ and potassium nitrate $\left(\mathrm{KNO}_{3}\right)$ rendered optimal performance at $18 \pm 2.12$ shoots when the nodal shoot segments of Citrus lemon were cultured, whereas half-strength MS media was used for the root induction of Citrus jambhiri Lush. 
TABLE 1. The percentage of shoot induction and average number of induced shoots from shoot tips of Citrus australasica cv. Tasty Green using full-strength and half-strength MS media

\begin{tabular}{lcc}
\hline Strength of media & Percentage of shoot induction $(\%)$ & $\begin{array}{c}\text { Average number of induced shoots } \\
(\mathrm{N})(\overline{\mathrm{x}} \pm \mathrm{s} . \mathrm{e})\end{array}$ \\
\hline Full-strength & 65 & $1.35 \pm 0.27^{\mathrm{a}}$ \\
Half-strength & 60 & $0.85 \pm 0.20^{\mathrm{a}}$ \\
\hline
\end{tabular}

*Column with same letter indicates that there was no significant difference between mean. (Independent $\mathrm{T}$ test, $\mathrm{p} \leq 0.05$ )

\section{THE INDUCTION OF SHOOTS WITH PLANT GROWTH REGULATOR BAP AND KINETIN}

Full-strength MS media was used to induce shoots with plant growth regulators BAP and Kinetin, in agreement with previous studies on citrus reporting on the superiority of full-strength over half-strength MS media in producing a higher number of regenerated shoots for citrus plants (Eed et al. 2011; Taye et al. 2018). Thus, full-strength MS media was selected for the induction of shoots in this investigation.

In the current study, the percentage of induced shoots for all treatments was at the range of 55 to $80 \%$, thereby indicating a high suitability of the full-strength MS media supplemented with plant growth regulators in facilitating explant growth. MS media supplemented with $2.0 \mathrm{mg} / \mathrm{L}$ of BAP particularly rendered the highest percentage of shoot induction, at $80 \%$. With reference to Table 2, shoot tips explants supplemented with $2.0 \mathrm{mg} / \mathrm{L}$ BAP produced the highest number of shoots and the highest average height of induced shoots at $1.80 \pm 0.27$ and $2.56 \pm 0.36 \mathrm{~cm}$, respectively. BAP at $2.0 \mathrm{mg} / \mathrm{L}$ was found to be the optimal concentration to induce shoots, increment of shoot length, as compared to other treatments in this study.

The optimal number of shoots at 1.80 is considered low when compared to other citrus species. However, the in vitro production of shoots may reflect upon the slow growth nature of the finger lime trees in the wild (Hardy et al. 2010). Figure 1 depicts the axillary shoots formed from shoot tip explants on different treatments of BAP after 6 weeks of culture. The number of shoots decreased when the concentration of BAP was raised to 3.0 and $4.0 \mathrm{mg} / \mathrm{L}$. This could be due to the fact that a higher concentration of BAP would interfere and disrupt optimal induction and proliferation of shoots in vitro (Nelson et al. 2015). With reference to Martin et al. (2006) and Venkatachalam et al. (2007), high concentrations of BAP can induce potential somaclonal variation resulting in abnormal phenotypes and non-true-to-type plants.

Mahmoud et al. (2020) reported that MS media supplemented with $2.2 \mu \mathrm{M}$ of BAP produced the highest percentage of shoot induction (above $80 \%$ ) and the treatment of MS media supplemented with $2.2 \mu \mathrm{M}$ of BAP, $60 \mu \mathrm{M}$ of silver thiosulfate (STS) and $0.70 \mu \mathrm{M}$ of gibberellic acid $\left(\mathrm{GA}_{3}\right)$ resulted in the highest number of shoot induction with an average of four shoots per explant. Previous studies on other in vitro citrus also highlighted the efficiency of BAP in inducing multiple shoots as compared to other cytokinins. Haripyaree et al. (2011) reported that the highest number of multiple shoot formation was observed in the combination of $0.25 \mathrm{mg} / \mathrm{L}$ BAP and $0.50 \mathrm{mg} / \mathrm{L} \mathrm{NAA}(4.7 \pm 0.5$ shoots per explant), followed by $1.0 \mathrm{mg} / \mathrm{L}$ BAP and $0.50 \mathrm{mg} / \mathrm{L}$ Kinetin $(4.4$ \pm 0.4 shoots per explant) from shoots tip explants of $C$. megaloxycarpa. Shoot tip explants of pummelo (Citrus grandis L. Osbeck) was reported to produce and average of 5.2 shoots when treated with $1.8 \mu \mathrm{M}$ of BAP (Paudyal $\&$ Haq 2000). Meanwhile, Singh et al. (1994) discovered that MS media supplemented with $1.0 \mathrm{mg} / \mathrm{L}$ BAP, 0.5 $\mathrm{mg} / \mathrm{L}$ Kinetin and $0.5 \mathrm{mg} / \mathrm{L}$ NAA gave the highest multiple shoot number and shoot length $(6.1 \pm 0.11$ and $2.6 \pm 0.09$ $\mathrm{cm}$, respectively) from shoot tips of $C$. reticulata. This treatment also worked optimally for $C$. limon explants in terms of the number of shoot multiplication, shoot length and number of leaves (Singh et al. 1994). Another study from Bhagat et al. (2012) reported that $3.0 \mathrm{mg} / \mathrm{L} \mathrm{BAP} \mathrm{is}$ optimal in inducing multiple shoots (4.02 shoots) and increasing shoot height $(1.81 \mathrm{~cm})$ for $C$. jambhiri. Besides, both shoot tips and nodal segments of sweet orange cv. Mosambi produced the maximum shoot length and highest number of leaves from combination of $2.0 \mathrm{mg} / \mathrm{L}$ BAP, $1.0 \mathrm{mg} / \mathrm{L}$ Kinetin and $0.1 \mathrm{mg} / \mathrm{L}$ NAA (Upadhyay et al. 2010). With reference to the reports as above, it was evident that BAP plays an important role in the induction of shoots and shoot elongation for various citrus cultivars. 
On the other hand, certain citrus species was reported to respond to Kinetin in terms of the initiation of shoots. Goswami et al. (2013) reported a lower number of shoots per explant at $1.2 \pm 0.14$ shoots in the treatment of MS media supplemented with $0.5 \mathrm{mg} / \mathrm{L}$ of Kinetin. Similar result was obtained in a study conducted by De Oliveira et al. (2016), whereby MS media supplemented with $1.0 \mathrm{mg} / \mathrm{L}$ of Kinetin rendered a mean number of 1.12 shoot for Citrus sinensis cv. Washington Navel. However, Mukhtar et al. (2005) reported that shoot tips of Citrus reticulata (Blanco) rendered the highest number of shoots at 7.99 shoots in the treatment of MS media supplemented with $1.5 \mathrm{mg} / \mathrm{L}$ Kinetin. In the current study, $3.0 \mathrm{mg} / \mathrm{L}$ of Kinetin rendered $1.25 \pm 0.23$ shoots, which is in contrast with the high induced shoot number as reported by Mukhtar et al. (2005).
The vast differences in the number of shoots produced can be attributed to the fact that the presence of endogenous hormones in plant cells influences the in vitro organogenesis of shoots. Hu et al. (2017) reported that the inhibition of in vitro shoot organogenesis in the basal end of citrus epicotyl was due to the presence of elevated levels of endogenous auxin. Besides, the synergistic and inhibitory interactions of exogenous and endogenous plant growth regulators are specific, as different species, genotype and explant source largely influences the response of plant cells and tissues (Mwaniki et al. 2019). Nevertheless, this signifies that both cytokinins, BAP, and Kinetin are commonly used to induce multiple shoots for most citrus species, with preference given to BAP in most literatures due to its superiority over Kinetin in inducing a higher number of shoots.

TABLE 2. The percentage of shoot induction, average number of induced shoots and average height of induced shoots on media supplemented with BAP and Kinetin

\begin{tabular}{|c|c|c|c|}
\hline Treatment $(\mathrm{mg} / \mathrm{L})$ & $\begin{array}{c}\text { Percentage of shoot induction } \\
\qquad(\%)\end{array}$ & $\begin{array}{l}\text { Average number of induced } \\
\text { shoots }(N)(\bar{x} \pm S . E)\end{array}$ & $\begin{array}{l}\text { Average height of induced } \\
\text { shoots }(\mathrm{cm})\left(\begin{array}{ll}\bar{x} & \pm \text { S.E }\end{array}\right)\end{array}$ \\
\hline 0.0 & 65 & $1.00 \pm 0.22^{b}$ & $0.99 \pm 0.21^{b}$ \\
\hline $0.1 \mathrm{BAP}$ & 65 & $1.10 \pm 0.22^{b}$ & $1.16 \pm 0.22^{b}$ \\
\hline $0.5 \mathrm{BAP}$ & 65 & $1.00 \pm 0.22^{\mathrm{b}}$ & $1.20 \pm 0.27^{\mathrm{b}}$ \\
\hline $1.0 \mathrm{BAP}$ & 60 & $1.00 \pm 0.22^{b}$ & $1.09 \pm 0.25^{b}$ \\
\hline $2.0 \mathrm{BAP}$ & 80 & $1.80 \pm 0.27^{\mathrm{a}}$ & $2.56 \pm 0.36^{\mathrm{a}}$ \\
\hline $3.0 \mathrm{BAP}$ & 70 & $1.10 \pm 0.22^{b}$ & $1.19 \pm 0.21^{\mathrm{b}}$ \\
\hline $4.0 \mathrm{BAP}$ & 60 & $0.80 \pm 0.19^{b}$ & $1.13 \pm 0.26^{b}$ \\
\hline 0.1 Kinetin & 60 & $0.80 \pm 0.17^{b}$ & $0.91 \pm 0.21^{\mathrm{b}}$ \\
\hline 0.5 Kinetin & 60 & $0.90 \pm 0.22^{b}$ & $0.87 \pm 0.21^{b}$ \\
\hline 1.0 Kinetin & 65 & $1.00 \pm 0.21^{\mathrm{b}}$ & $0.97 \pm 0.19^{b}$ \\
\hline 2.0 Kinetin & 55 & $0.70 \pm 0.16^{b}$ & $0.95 \pm 0.20^{\mathrm{b}}$ \\
\hline 3.0 Kinetin & 70 & $1.25 \pm 0.23^{\mathrm{ab}}$ & $1.18 \pm 0.22^{\mathrm{ab}}$ \\
\hline 4.0 Kinetin & 60 & $1.15 \pm 0.24^{b}$ & $1.18 \pm 0.24^{b}$ \\
\hline
\end{tabular}

*Column with same letter indicates that there was no significant difference between means. (Duncan's test, $\mathrm{p} \leq 0.05$ ) 

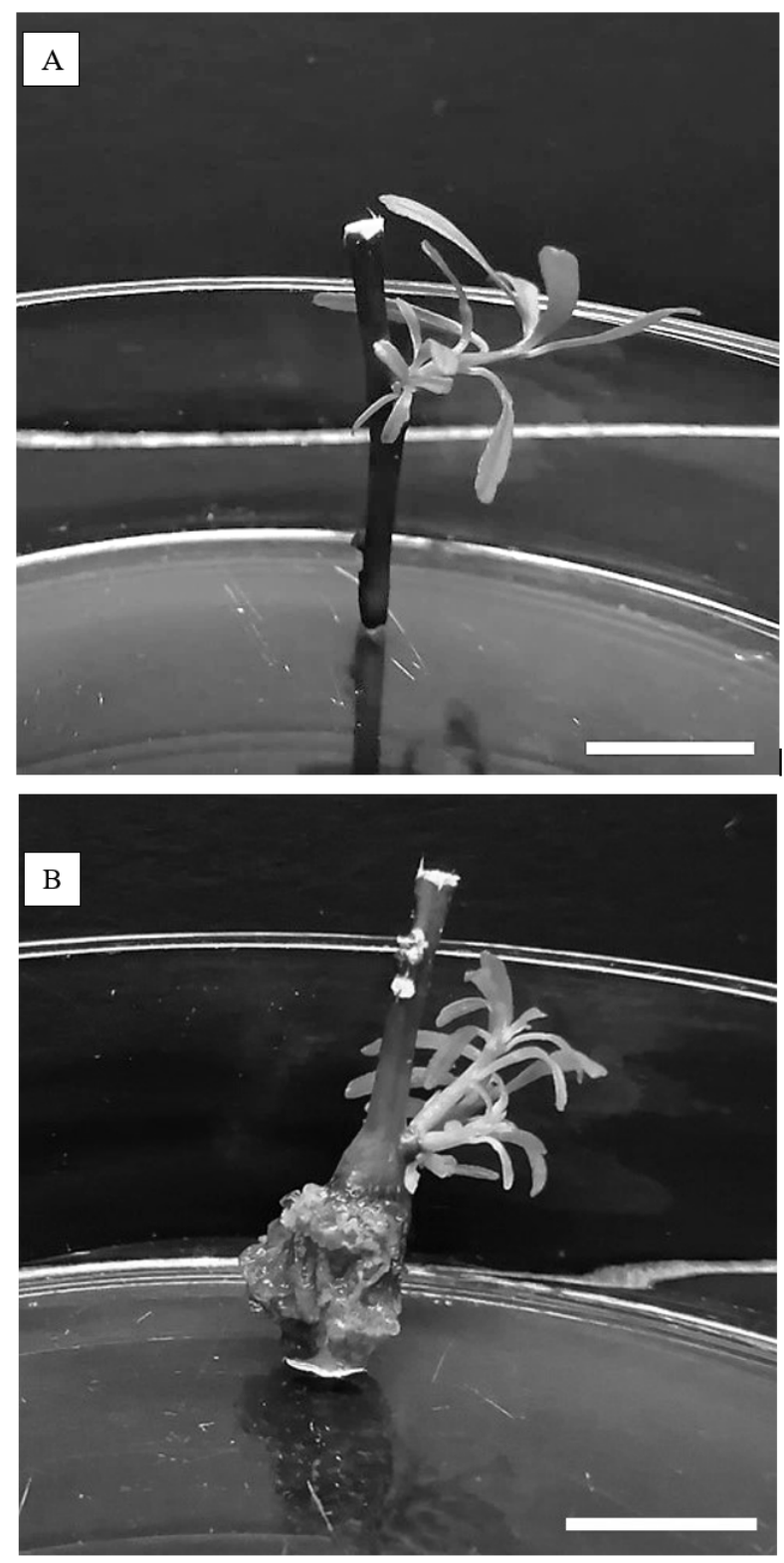

FIGURE 1. The induction of shoots from shoot tip explants in different treatments of BAP after 6 weeks of culture (A) Control, MS media (B) MS media supplemented with $2.0 \mathrm{mg} / \mathrm{L}$ BAP. Scale bars represent $1 \mathrm{~cm}$

\section{CONCLUSION}

Sterile cultures and the induction of shoots from shoot tip explants of $C$. australasica cv. Tasty Green were successfully established in this study. The current report also indicated that there was no significant difference in terms of the number of induced shoots for full and halfstrength MS media. The treatment of full-strength MS media supplemented with $2.0 \mathrm{mg} / \mathrm{L}$ BAP resulted in the highest number of induced shoots and shoot elongation as compared to other BAP and Kinetin treatments. 


\section{ACKNOWLEDGEMENTS}

The authors would like to acknowledge Universiti Sains Malaysia for funding the project under the USM Research University TOP DOWN Grant (1001/ PBIOLOGI/8070004).

\section{REFERENCES}

Al-Khayri, J.M. \& Al-Bahrany, A.M. 2001. In vitro micropropagation of Citrus aurantifolia (lime). Current Science 81(9): 1242-1246.

Bhagat, A., Pati, P.K., Virk, G.S. \& Nagpal, A. 2012. An efficient micropropagation protocol for Citrus jambhiri Lush. and assessment of clonal fidelity employing anatomical studies and RAPD markers. In Vitro Cellular \& Developmental Biology-Plant 48(5): 512-520.

De Oliveira, M., Thomson, J.G. \& Stover, E. 2016. Highefficiency propagation of mature 'Washington Navel' orange and juvenile 'Carrizo' citrange using axillary shoot proliferation. HortTechnology 26(3): 278-286.

Delort, E. \& Jaquier, A. 2009. Novel terpenyl esters from Australian finger lime (Citrus australasica) peel extract. Flavour and Fragrance Journal 24(3): 123-132.

Delort, E., Jaquier, A., Decorzant, E., Chapuis, C., Casilli, A. \& Frérot, E. 2015. Comparative analysis of three Australian finger lime (Citrus australasica) cultivars: Identification of unique citrus chemotypes and new volatile molecules. Phytochemistry 109: 111-124.

Eed, A.M., Begum, H., Sivaramakrishnan, S., Silva, J.O., Amrender-Reddy, S. \& Al-gabal, A.Q. 2011. Rapid protocol for in vitro multiplication of Citrus limonia Osbeck rootstock. International Journal of Plant Developmental Biology 5(1): 78-82.

Fatonah, S., Lestari, W., Isda, M. \& Purba, L. 2018. In vitro shoot regeneration of Citrus nobilis Lour. from intact seed and cotyledon explants. SABRAO Journal of Breeding and Genetics 50(2): 168-179.

Goswami, K., Sharma, R., Singh, P. \& Singh, G. 2013. Micropropagation of seedless lemon (Citrus limon L. cv. Kaghzi Kalan) and assessment of genetic fidelity of micropropagated plants using RAPD markers. Physiology and Molecular Biology of Plants 19(1): 137-145.

Hardy, S., Wilk, P., Viola, J. \& Rennie, S. 2010. Growing Australian native finger limes. Primefact 979: 1-11.

Haripyaree, A., Kshetrimayum Guneshwor, H.S. \& Damayanti, M. 2011. In vitro propagation of Citrus megaloxycarpa. Environmental and Experimental Biology 9: 129-132.

Hu, W., Fagundez, S., Katin-Grazzini, L., Li, Y., Li, W., Chen, Y., Wang, X., Deng, Z., Xie, S., McAvoy, R.J. \& Li, Y. 2017. Endogenous auxin and its manipulation influence in vitro shoot organogenesis of citrus epicotyl explants. Horticulture Research 4: 17071.

Kawaii, S., Tomono, Y., Ogawa, K., Sugiura, M., Yano, M., Yoshizawa, Y., Ito, C. \& Furukawa, H. 2001. Antiproliferative effect of isopentenylated coumarins on several cancer cell lines. Anticancer Research 21(3B): 1905-1911.

Konczak, I., Zabaras, D., Dunstan, M. \& Aguas, P. 2010 Antioxidant capacity and hydrophilic phytochemicals in commercially grown native Australian fruits. Food Chemistry 123(4): 1048-1054.

Koskinen, J. 2016. Native Australian Citrus. http://citruspages. free.fr/australian.html\#finger. Accessed on 21 July 2018.

Mabberley, D.J. 1998. Australian Citreae with notes on other Aurantioideae (Rutaceae). Telopea 7(4): 333-344.

Mahmoud, L.M., Grosser, J.W. \& Dutt, M. 2020. Silver compounds regulate leaf drop and improve in vitro regeneration from mature tissues of Australian finger lime (Citrus australasica). Plant Cell, Tissue and Organ Culture 141: 455-464.

Martin, K.P., Pachathundikandi, S.K., Zhang, C.L., Slater, A. \& Madassery, J. 2006. RAPD analysis of a variant of banana (Musa sp.) cv. grande naine and its propagation via shoot tip culture. In Vitro Cellular \& Developmental BiologyPlant 42: 188-192.

Mukhtar, R., Khan, M.M., Fatima, B., Abbas, M. \& Shahid, A. 2005. In vitro regeneration and multiple shoots induction in Citrus reticulata (Blanco). International Journal of Agriculture and Biology 7: 414-416.

Mwaniki, W.I., Lubabali, A.H., Asava, K.K., Agwanda, C.O. \& Anami, S.E. 2019. Effects of genotype and plant growth regulators on callus induction in leaf cultures of Coffea arabica L. F1 hybrid. African Journal of Biotechnology 18(31): 1004-1015.

Nelson, B.J., Asare, P.A. \& Junior, R.A. 2015. In vitro growth and multiplication of pineapple under different duration of sterilization and different concentrations of benzylaminopurine and sucrose. Biotechnology 14(1): 35-40.

Netzel, M., Netzel, G., Tian, Q., Schwartz, S. \& Konczak, I. 2007. Native Australian fruits - A novel source of antioxidants for food. Innovative Food Science \& Emerging Technologies 8(3): 339-346.

Normah, M.N., Hamidah, S. \& Ghani, F.D. 1997. Micropropagation of Citrus halimii - An endangered species of South-east Asia. Plant Cell, Tissue and Organ Culture 50(3): 225-227.

Paudyal, K.P. \& Haq, N. 2000. In vitro propagation of pummelo (Citrus grandis L. Osbeck). In Vitro Cellular \& Developmental Biology-Plant 36(6): 511-516.

Pham-Huy, L.A., He, H. \& Pham-Huy, C. 2008. Free radicals, antioxidants in disease and health. International Journal of Biomedical Science: IJBS 4(2): 89.

Rathore, J.S., Rathore, M.S., Singh, M., Singh, R.P. \& Shekhawat, N.S. 2007. Micropropagation of mature tree of Citrus limon. Indian Journal of Biotechnology 6: 239-244.

Rizvi, S., Raza, S.T., Ahmed, F., Ahmad, A., Abbas, S. \& Mahdi, F. 2014. The role of vitamin E in human health and some diseases. Sultan Qaboos University Medical Journal 14(2): e157. 
Shende, C.B. \& Manik, S.R. 2015. Direct regeneration of shoot from axillary bud of Citrus reticulate. International Journal of Agricultural Technology 11(6): 1401-1409.

Silva, R.P., Souza, A.J., Mendes, B.M.J. \& Mourão Filho, F.A.A. 2010. Sour orange bud regeneration and in vitro plant development related to culture medium composition and explant type. Revista Brasileira de Fruticultura 32(1): 1-8.

Singh, S., Ray, B.K., Bhattacharyya, S. \& Deka, P.C. 1994. In vitro propagation of Citrus reticulata Blanco and Citrus limon Burm.f., HortScience 29(3): 214-216.

Stamford, N.P. 2012. Stability, transdermal penetration, and cutaneous effects of ascorbic acid and its derivatives. Journal of Cosmetic Dermatology 11(4): 310-317.

Taye, M.G., Debesay, B., Tesfahun, Y. \& Brhanu, A. 2018. Optimization of an in vitro regeneration protocol for Rough Lemon rootstock (Citrus jambhiri L.) via direct organogenesis. Advances in Crop Science and Technology 6(1): 329-334

Upadhyay, S., Syamal, M.M. \& Itoo, H. 2010. Micropropagation of sweet orange cv. Mosambi through shoot tips and nodal segments. Indian Journal of Horticulture 67: 21-25.

Venkatachalam, L., Sreedhar, R.V. \& Bhagyalakshmi, N. 2007. Genetic analyses of micropropagated and regenerated plantlets of banana as assessed by RAPD and ISSR markers. In Vitro Cellular \& Developmental Biology-Plant 43: $267-274$
Vibhute, M., Tripathi, M.K., Tiwari, R., Baghel, B.S. \& Tiwari, S. 2012. Interspecific morphogenic ability differences in citrus. Journal of Agricultural Technology 8(2): 625-638.

Yasmina, S. \& Fazal, S. 2016. Australian Native Plants: Cultivation and Uses in the Health and Food Industries. Boca Raton: CRC Press.

Dahmendra Sriskanda, Khoy Siong Poi, Najwa Amalina Haradzi, Sreeramanan Subramaniam \& Bee Lynn Chew*

School of Biological Sciences

Universiti Sains Malaysia

11800 Pulau Pinang

Malaysia

Nurulhikma Md Isa

Department of Biological Sciences \& Biotechnology

Faculty of Science \& Technology

Universiti Kebangsaan Malaysia

43600 UKM Bangi, Selangor Darul Ehsan

Malaysia

*Corresponding author; email: beelynnchew@usm.my

Received: 19 February 2020

Accepted: 8 October 2020 